\section{Toku toa, he toa rangatira: \\ Fearlessness and Indigenous Scholarship}

\section{Jani Wilson}

Auckland University of Technology

A well-known whakataukī (aphorism, proverb) tells us toku toa, he toa rangatira, quite literally 'my courage is inherited'. Wairaka is known as an impressive young wahine from pre-colonial times who, in the face of a life or death situation, stood up to adversity to supersede an important, long held tikanga Māori (protocol) to save the Ngāti Awa iwi. She is my whāea tipuna (ancestress) and because of her bravery, I like to carry her with me in my academic career as a screen studies scholar. Ensuring academic disciplines endure and are relevant throughout the generations requires consistently robust research, dynamic teaching, and leadership; but challenging academia with Indigenous knowledge goes beyond this. As Indigenous academic scholars, we must commit to satiating the academy with our research and teaching to appeal to the discipline's status quo, at the same time as upholding the values, expectations and ideals of our communities, those to whom we return once projects are complete. Therefore, Indigenous research is never truly over. The marriage between the discipline and our respective cultures however is never straightforward. Indigenous scholarship takes a much greater level of fearlessness because we must combat potential exclusion from the discipline that we are carving the outlines of our culture into. Thus, we must choose to either blend into the grooves of the existing disciplinary carvings, or to accept that we are a new adze. This is often met with obstructions. Primarily relying on critical Kaupapa Māori analysis comparing the existing and prospective fields of knowledge, this paper considers the potential of Indigenous research as a collective of holistic research strategies. It underlines some of the challenges associated with implementing Indigenous knowledge and diverting from disciplinary norms. In the way that our whāea tipuna Wairaka did, we can challenge the long held tikanga - the rules and strictures - that have sustained and satiated our disciplines for generations, to save or evolve our disciplines into the future. Like Wairaka, and many of your brave ancestors before you, we must be prepared to stand alone, and to be courageous as per our inheritance.
Orcid number 0000-0001-6774-1696
KEYWORDS

Challenge, fearlessness, Indigenous, Mātauranga Māori 